УДК 621.891

DOI: $10.18372 / 0370-2197.3(88) .14920$

\author{
Р. Г. МНАЦАКАНОВ, О. О. МІКОСЯНЧИК., О. Є. ЯКОБЧУК, А. М. ХІМКО, \\ O. В. ХАРЧЕНКО
}

Національний авіаційний університет, Украӥна

\title{
ОГЛЯД КЛАСИФІКАЦІЙ ЗА ФІЗИКО-МЕХАНІЧНИМИ ТА ЕКСПЛУАТАЦЙНИМИ ВЛАСТИВОСТЯМИ МАСТИЛ ЗАКОРДОННОГО ВИРОБНИЦТВА
}

В статті викладено огляд закордонних мастил за фізико-механічними та експлуатаційними характеристиками. Представлено класифікаиії за системою NLGI ma DIN. Показано різниия між ицими системами та особливості класифікування олив та мастил. Представлено вимоги до якості мастил та олив згідно категорій NLGI, DIN. Асортимент авіаційних пластичних мастил закордонного виробництва досить повно представлено в роботі. Представлено аналіз мастильних матеріалів: компанії NYCO (Франція), торгової марки «AeroShell» (Нідерланди - Великобританія), торгової марки «Rоусо» (Сполучені Штати Америки), компанії WEGO (Чеська Республіка), компанії "ЭкспертОйл" (Російська Федерачія). Проаналізовано найбільш вживані та розповсюджені мастильні авіаційні матеріали. Показано робочі температурні вимоги до мастил та область застосування мастил з різними ступнями в'язкості та межи витривалості.

Ключові слова: класифікація олив, мастил, роботоздатність, авіаційні мастила, автомобільні мастила, знос, пенетрація, консистенція, надійність, тертя.

Вступ. Роботоздатність техніки і ефективність функціонування народного господарства залежать від їх забезпеченості високоефективними мастильними матеріалами (оливами, мастилами, змащувально-охолоджувальними рідинами). Виготовлення високотехнологічних та високоефективних авіаційних, промислових та автомобільних мастильних матеріалів є однією 3 першочергових задач для підвищення надійності машин і механізмів [1].

Основним призначенням мастил є забезпечення зниження тертя і зносу в деталях тертя, збільшення терміну служби обладнання та періоду між обслуговуванням транспортних засобів та промислового обладнання [1, 2].

Існуючі системи класифікації [3, 4]мастильних матеріалів за фізикомеханічними та експлуатаційними властивостями дозволяють більш ефективно використовувати мастильні матеріали в вузлах тертя машин і механізмів. В роботі розглянуто системи класифікації та стандартизації мастил, розроблені провідними науковими закордонними установами.

Система класифікації. Класифікація мастил NLGI розроблена Американським національним інститутом пластичних мастил [5, 6]. У співпраці з ASTM International та SAE International, NLGI розробила категорію якості автомобільних мастил, визначених у стандарті ASTM D4950 «Стандартна класифікація та специфікація автомобільних сервісних мастил» [7].

Класифікація за NLGI включає розподіл мастил за категоріями ступеня консистенції (ступінь в'язкості або густини) та категоріями якості.

За категоріями ступеня консистенції мастила ділять на класи в залежності від рівня пенетрації - чим більше чисельний показник пенетрації, тим м'якше мастило. Відповідно до загальноприйнятої методики, визначення показника пе- 
нетрації проводиться за допомогою пенетрометра 3 конусом, який опускають на п'ять секунд в мастило при температурі $25{ }^{\circ} \mathrm{C}$ [8]. Глибина занурення конуса вимірюється і виражається в десятих частках міліметра (рис. 1). Зазвичай пенетрацію визначають як у перемішаного, так і не перемішаного мастила. Різниця цих показників характеризує стабільність мастила і здатність витримувати зовнішній механічний вплив.

Категорія NLGI

Показник пенетрації (0,1 мм)
000

$445-475$

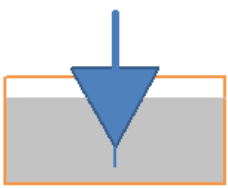

2

$265-295$

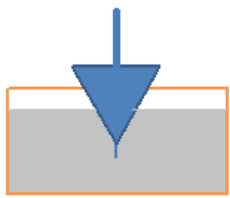

6

$85-115$

Рис. 1. Схема відповідності чисельних значень пенетрації та категорії ступеня консистенції мастила за NLGI.

Класифікація NLGI пластичних мастил за консистенцісю включас дев'ять категорій - від 000 до 6 (табл. 1) [8]:

- категорії 000 і 00 є напіврідкими мастилами, що використовуються в якості альтернативи оливам в механізмах і централізованих системах змащення з малим перетином каналів, по яким подається олива (наприклад, в двигунах сучасних вантажівок);

- категорії 0 і 1 призначені для застосування в головних централізованих системах змащення (наприклад промислове обладнання, вантажні автомобілі);

- категорії 2 і 3 використовуються в основному для змащення підшипників (категорія 2 найбільш поширена серед пластичних мастил для легкового транспорту);

- категорії 4 і 6 представляють виключно густі мастила і використовуються рідко.

Таблиияя 1

Класифікація NLGI пластичних мастил за консистенцією

\begin{tabular}{|c|c|c|c|}
\hline $\begin{array}{l}\text { Категорія } \\
\text { NLGI }\end{array}$ & $\begin{array}{c}\text { Показник пенетрації } \\
(0,1 \text { мм) }\end{array}$ & Консистенція & Призначення \\
\hline 000 & $445-475$ & дуже рідка & \multirow{2}{*}{$\begin{array}{c}\text { зубчасті передачі закрито- } \\
\text { го типу }\end{array}$} \\
\hline 00 & $400-430$ & рідка & \\
\hline 0 & $355-385$ & напіврідка & \multirow{2}{*}{$\begin{array}{c}\text { центральні системи зма- } \\
\text { щування }\end{array}$} \\
\hline 1 & $310-340$ & дуже м'яка & \\
\hline 2 & $265-295$ & м'яка & $\begin{array}{c}\text { Шарикові / роликові під- } \\
\text { шипники }\end{array}$ \\
\hline 3 & $220-250$ & напівтверда & \multirow{2}{*}{$\begin{array}{c}\text { Високошвидкісні підшип- } \\
\text { ники } \\
\end{array}$} \\
\hline 4 & $175-205$ & тверда & \\
\hline 5 & $130-160$ & дуже тверда & \multirow{2}{*}{$\begin{array}{c}\text { зубчасті передачі відкри- } \\
\text { того типу }\end{array}$} \\
\hline 6 & $85-115$ & \begin{tabular}{|} 
особливо твер- \\
да
\end{tabular} & \\
\hline
\end{tabular}

За категоріями якості згідно класифікації NLGI існує 5 класів консистентних мастил: LA, LB, GA, GB, GC [9]. Для визначення відповідності мастила 
певному класу визначається ряд його властивостей: пенетрація, температура краплепадіння, стійкість до окислення і випаровування, зміни консистенції, антикорозійних властивостей, сумісність 3 еластомерами, низькотемпературний момент обертання і т.д. (табл. 2).

Таблиия 2

Обов'язкові випробування консистентних мастил при визначенні категорії якості NLGI

\begin{tabular}{|c|c|c|c|c|c|c|}
\hline \multirow{2}{*}{$\begin{array}{c}\text { Стандарт } \\
\text { ASTM }\end{array}$} & \multirow{2}{*}{ Випробування } & \multicolumn{5}{|c|}{ Категорія якості NLGI } \\
\hline & & LA & LB & GA & GB & GC \\
\hline D 217 & Пенетрація & + & + & + & + & + \\
\hline D 566 & $\begin{array}{c}\text { Температура краплепа- } \\
\text { діння }\end{array}$ & + & + & + & + & + \\
\hline D 1264 & Вимивання водою & - & - & - & + & + \\
\hline D 1742 & $\begin{array}{c}\text { Температура виділення } \\
\text { оливи }\end{array}$ & - & + & - & + & + \\
\hline D 1743 & $\begin{array}{c}\text { Антикорозійні властивос- } \\
\text { ті }\end{array}$ & - & + & - & + & + \\
\hline D 2266 & $\begin{array}{l}\text { Знос на чотирьохкулько- } \\
\text { вій машині тертя (ЧМТ) }\end{array}$ & + & + & - & + & + \\
\hline D 2596 & Граничний тиск на ЧМТ & - & + & - & - & + \\
\hline D 3527 & $\begin{array}{c}\text { Стійкість до високої тем- } \\
\text { ператури }\end{array}$ & - & - & - & + & + \\
\hline D 4170 & Питинговий знос & - & + & - & + & + \\
\hline D 4289 & Сумісність 3 еластомірами & + & + & - & + & + \\
\hline D 4290 & Текучість & - & - & - & + & + \\
\hline D 4693 & $\begin{array}{c}\text { Низькотемпературний } \\
\text { момент обертання }\end{array}$ & - & + & + & + & + \\
\hline
\end{tabular}

Розглянемо представлені NLGI категорії якості докладніше.

Мастила категорії NLGI LA [9]: використовуються для змащування елементів ходової частини та шарнірних з'єднань легкових автомобілів та інших транспортних засобів 3 легким режимом роботи. Вимоги до якості. Мастила повинні задовільно змащувати елементи ходової частини і шарнірні з'єднання при частій заміні мастила (в легкових автомобілях через кожні 3200 км або частіше). Мастила повинні бути стійкими до окислення і зміни консистенції, а також забезпечувати ефективні антикорозійні та протизношувальні властивості триботехнічних елементів шарнірів та ходової частини в умовах малого навантаження. Зазвичай рекомендуються для даної категорії мастила консистенції NLGI 2, але аналогічно можуть бути використані мастила інших ступенів консистенції NLGI.

Мастила категорії NLGI LB [10]: використовуються для змащування елементів ходової частини та шарнірних з'єднань легкових автомобілів, вантажівок та інших транспортних засобів, що працюють в умовах як легкого, так і важкого режиму. До важкого режиму слід віднести режим, для якого характерні великий інтервал заміни мастила, великі навантаження, вібрації, поява в мастилі під час експлуатації води або інших забруднень. Це мастила вищої якості для ходової частини. Вимоги до якості. Мастила повинні задовільно змащувати елементи 
ходової частини і шарнірні з'єднання при температурі від -40 до $+120{ }^{\circ} \mathrm{C}$ при подовженому інтервалі заміни мастила (в легкових автомобілях більше 3200 км). Мастила повинні бути стійкими до окислення і зміни консистенції, а також забезпечувати ефективні антикорозійні та протизношувальні властивості триботехнічних елементів шарнірів та ходової частини в умовах забрудненості і великих навантажень. Зазвичай рекомендуються мастила консистенції NLGI 2, але аналогічно можуть бути використані мастила інших ступенів консистенції NLGI.

Мастила категорії NLGI GA: використовуються для змащування підшипників коліс легкових автомобілів, вантажівок та інших транспортних засобів, що працюють в звичайних умовах експлуатації в легкому режимі при частій заміні мастила. Вимоги до якості. Мастила повинні задовільно змащувати підшипники в температурному діапазоні від -20 до +70 С. Додаткових вимог немає.

Мастила категорії NLGI GB: використовуються для змащування підшипників коліс легкових автомобілів, вантажівок та інших транспортних засобів, що працюють як в легкому, так і в помірному режимі. Помірний режим - це звичайні умови експлуатації, які бувають у більшості транспортних засобів. Вимоги до якості. Мастила повинні забезпечувати ефективне змащування контактних поверхонь в широкому інтервалі температур - від -40 , до $+120{ }^{\circ} \mathrm{C}$ і навіть до $+160^{\circ} \mathrm{C}$. Мастила повинні бути стійкими до окислення, випаровування, зміни консистенції, ефективно захищати підшипники від корозії і зносу. Зазвичай рекомендуються мастила консистенції NLGI 2, але аналогічно можуть бути використані мастила інших ступенів консистенції NLGI - NLGI 1 i NLGI 3.

Мастила категорії NLGI GC: використовуються для змащування підшипників коліс легкових автомобілів, вантажівок та інших транспортних засобів, що працюють як в легкому, так і у важкому режимах. Важкий режим характерний для умов експлуатації транспортних засобів, підшипники яких нагріваються до високої температури. Це транспортні засоби з дисковими гальмами, які працюють в нестаціонарному «запуск-зупинка» режимі (автобуси, таксі, міські поліцейські автомобілі і т.д.) або в режимі важкого гальмування (буксирування, важка їзда в горах і т.д.). В даний час це мастила вищої якості для підшипників коліс транспортних засобів. Вимоги до якості. Мастила повинні забезпечувати ефективне змащування контактних поверхонь в широкому інтервалі температур - від -40 , до $+160{ }^{\circ} \mathrm{C}$ і навіть до $+200{ }^{\circ} \mathrm{C}$. Мастила повинні бути стійкими до окислення, випаровування, зміни консистенції, забезпечувати ефективний захист підшипників від корозії і зносу. Зазвичай рекомендуються мастила консистенції NLGI 2 , але аналогічно можуть бути використані мастила інших ступенів консистенції NLGI - NLGI 1 i NLGI 3.

\section{Маркування консистентних мастил NLGI.}

NLGI зберігає юрисдикцію щодо позначення та визначення категорій, які вона публікує у своїй "системі класифікації шасі та колісних підшипників". NLGI також створив символ, сертифікаційний знак NLGI, який можна використовувати на контейнерах 3 мастилом для реклами своєї категорії згідно міжнародному стандарту ASTM D4950 [7].

Для позначення категорій мастил, NLGI використовує символ «NLGI», який присвоюється лише мастилам найвищої категорії якості: GC, LB i GC-LB (рис. 2). 

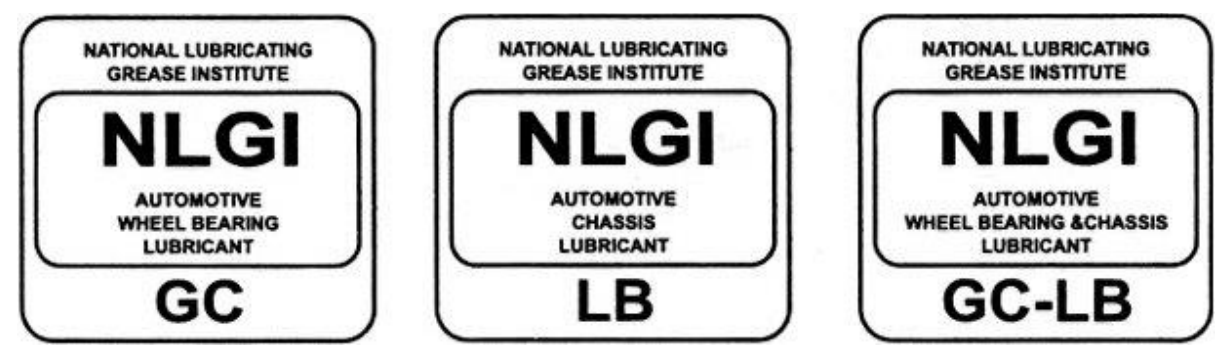

Рис. 2. Знаки відповідності категоріям NLGI.

Мастила інших категорій цим символом не позначаються, тільки на етикетці або в описі зазвичай вказуються категорія якості NLGI GA, NLGI GB, NLGI LA. В Європі подібна класифікація застосовується досить рідко, європейський аналог даної класифікації відсутній.

Система класифікації DIN. Німецький інститут по стандартизації (нім. Deutsches Institut für Normung (DIN) [11]- національна організація Німеччини по розробці стандартів. Членами DIN є різні підприємства, спілки, державні організації, торговельні фірми і наукові інститути, які накопичили значний досвід у розробках нормативних документів

Головним завданням DIN є розробка нормативно-технічної документації (стандарти, технічні умови, правила і т. п.). Інтенсивна робота німецьких експертів в сфері міжнародної стандартизації та нормування зробила DIN одним із загальновизнаних світових лідерів з розробки стандартів та інших нормативних документів. Всього в DIN входять 74 нормативних комітети, що займаються розробкою стандартів та іншої документації.

Німецький стандарт DIN 51502-1990 [12] закріпив єдину систему позначення та ідентифікації мастильних матеріалів. Уніфікована класифікація мастил за типом, застосуванням, консистенцією, водостійкістю, максимальною і мінімальною експлуатаційною температурою, типом присадок, що входять в консистентне мастило, дозволяє швидко і легко підібрати мастило для конкретних умов використання відповідного механізму, розшифрувавши всі характеристики за позначенням згідно маркуванню. Стандарт встановлює класифікацію мастил в залежності від галузей застосування, типу дисперсійного середовища, наявності в них протизношувальних і антифрикційних присадок, наповнювачів, а також враховує їх водостійкість і температурний діапазон застосування.

Стандарт DIN 51825: 2004 «Мастила. Мастила густі типу К. Класифікація та вимоги (Lubricants - Lubricating Greases K - Classification And Requirements) [13] застосовується до пластичних мастил, які відповідають від 0 до 4 категорії консистенції за класифікацією NLGI (табл. 1) та призначені для змащування роликових підшипників кочення, підшипників ковзання, поверхонь ковзання.

Позначення мастил за стандартами DIN 51502, DIN 51825 [12, 13] включає п'ять груп символів 3 літер та цифр:

- перша - позначається однією або двома літерами і вказує на галузь застосування мастила (табл. 3 );

- друга - позначається однією або декількома літерами і вказує на наявність в мастилі присадок і наповнювачів (табл. 4) та тип синтетичної основи (мастило на основі мінеральної оливи не має символу) (табл. 5); 
- третя - цифровий код (від 000 до 6), що несе інформацію про відповідність мастила певній категорії консистенції за класифікацією NLGI (табл. 1)[ 9];

- четверта - символ з літери, що позначає верхню температурну межу роботоздатності мастила і його водостійкість при контрольній температурі (табл. 6);

- п'ята - цифровий символ, що позначає нижню температурну межу роботоздатності мастила (табл. 7).

Пластичні мастила також позначаються геометричним символом: символом пластичних мастил на мінеральній основі $є$ трикутник, на синтетичній основі - ромб.

Таблиия 3

Позначення пластичних мастил відповідно до їх застосування

\begin{tabular}{|c|c|}
\hline $\begin{array}{c}\text { Тип пластичного мастила відповідно до типу вузла тер- } \\
\text { тя }\end{array}$ & $\begin{array}{l}\text { Позначення лі- } \\
\text { терою }\end{array}$ \\
\hline $\begin{array}{l}\text { Пластичні мастила для роликових підшипників кочення, } \\
\text { підшипників ковзання, поверхонь ковзання за стандартом } \\
\text { DIN } 51825 \text { [13] }\end{array}$ & $\mathrm{K}^{1)}$ \\
\hline $\begin{array}{l}\text { Пластичні мастила для закритих приводів за стандартом } \\
\text { DIN } 51826 \text { [14] }\end{array}$ & $\mathrm{G}$ \\
\hline $\begin{array}{l}\text { Пластичні мастила для відкритих приводів, зубчастих при- } \\
\text { водів (адгезивні мастила без бітуму) }\end{array}$ & OG \\
\hline $\begin{array}{l}\text { Пластичні мастила для підшипників ковзання і ущільнюва- } \\
\text { чів 2) }\end{array}$ & $\mathrm{M}$ \\
\hline
\end{tabular}

Таблиия 4

Додаткове позначення літерою для пластичних мастил за стандартами DIN 51502, DIN 51825 / 51826

\begin{tabular}{|c|l|}
\hline $\begin{array}{c}\text { Додаткове по- } \\
\text { значення лі- } \\
\text { терою }\end{array}$ & \multicolumn{1}{|c|}{ Тип мастил } \\
\hline $\mathrm{F}$ & $\begin{array}{l}\text { Для мастил с твердими добавками (графіт, дисульфід молі- } \\
\text { бдену та ін.) }\end{array}$ \\
\hline $\mathrm{L}$ & $\begin{array}{l}\text { Для мастил з активними речовинами, призначеними для пі- } \\
\text { двищення антикорозійних властивостей та / або стабільності } \\
\text { проти окислення }\end{array}$ \\
\hline $\mathrm{P}$ & $\begin{array}{l}\text { Для мастил з антифрикційними та протизношувальними } \\
\text { присадками для зниження тертя і зношування в умовах змі- } \\
\text { шаного режиму мащення при експлуатації та / або для під- } \\
\text { вищення гранично допустимого навантаження }\end{array}$ \\
\hline
\end{tabular}




\section{Таблиия 5}

Маркування мастил на синтетичній або напівсинтетичній основі додатковою літерою

\begin{tabular}{|l|c|}
\hline $\begin{array}{c}\text { Тип синтетичної або напівсинтетичної основи плас- } \\
\text { тичного мастила }\end{array}$ & $\begin{array}{c}\text { Позначення літе- } \\
\text { рою }\end{array}$ \\
\hline Поліефірна базова олива & $\mathrm{E}$ \\
\hline Фторвуглеводна базова олива & $\mathrm{FK}$ \\
\hline Синтетична вуглеводнева базова олива & $\mathrm{HC}$ \\
\hline Базова олива на основі ефірів фосфорної кислоти & $\mathrm{PH}$ \\
\hline Полігліколева базова олива & $\mathrm{PG}$ \\
\hline Силіконова базова олива & $\mathrm{SI}$ \\
\hline Інші типи базових олив & $\mathrm{X}$ \\
\hline
\end{tabular}

Таблиия 6

Додаткові позначення літерою за стандартом DIN 51825/51826

\begin{tabular}{|c|c|c|}
\hline $\begin{array}{l}\text { Додаткова } \\
\text { літера }\end{array}$ & $\begin{array}{c}\text { Верхня робоча темпе- } \\
\text { ратура }^{1)}\end{array}$ & $\begin{array}{c}\text { Водостійкість за DIN } 51807 \text { [16], ч. } 1 . \\
\text { Ступінь оцінки за DIN 51807 }\end{array}$ \\
\hline $\mathrm{C}$ & \multirow{2}{*}{$+60{ }^{\circ} \mathrm{C}$} & 0 - 40 або $1-40$ \\
\hline $\mathrm{D}$ & & 2 - 40 або 3 - 40 \\
\hline $\mathrm{E}$ & \multirow{2}{*}{$+80{ }^{\circ} \mathrm{C}$} & 0 - 40 або 1 - 40 \\
\hline $\mathrm{F}$ & & 2 - 40 або 3 - 40 \\
\hline $\mathrm{G}$ & \multirow{2}{*}{$+100^{\circ} \mathrm{C}$} & 0 - 90 або 1 - 90 \\
\hline $\mathrm{H}$ & & 2 - 90 або 3 - 90 \\
\hline $\mathrm{K}$ & \multirow{2}{*}{$+120^{\circ} \mathrm{C}$} & 0 - 90 або 1 - 90 \\
\hline M & & 2 - 90 або 3 - 90 \\
\hline $\mathrm{N}$ & $+140^{\circ} \mathrm{C}$ & \multirow{6}{*}{$\begin{array}{l}\text { За домовленістю } \\
\text { (немає вимог) }\end{array}$} \\
\hline $\mathrm{P}$ & $+160^{\circ} \mathrm{C}$ & \\
\hline $\mathrm{R}$ & $+180^{\circ} \mathrm{C}$ & \\
\hline $\mathrm{S}$ & $+200^{\circ} \mathrm{C}$ & \\
\hline $\mathrm{T}$ & $+220^{\circ} \mathrm{C}$ & \\
\hline $\mathrm{U}$ & Понад $+220^{\circ} \mathrm{C}$ & \\
\hline \multicolumn{3}{|c|}{$\begin{array}{l}\text { 1) «Верхня робоча температура» для неперервного мащення відповідас максимальній } \\
\text { контрольній температурі при випробуваннях за DIN 51819-2 : 2016 [17] та/або DIN } \\
51821, \text { ч.2 [18] якщо ходове випробування виконано }\end{array}$} \\
\hline \multicolumn{3}{|c|}{ 2) 0 - зміни відсутні; 1 - незначні зміни; 2 - значні зміни; 3 - дуже значні зміни } \\
\hline
\end{tabular}


Таблиия 7

Додаткові числа при маркуванні пластичних мастил за стандартами DIN 51502, DIN 51825/51826

\begin{tabular}{|c|c|}
\hline $\begin{array}{c}\text { Додатковий ін- } \\
\text { декс }\end{array}$ & Мінімальна експлуатаційна температура \\
\hline-10 & $-10^{\circ} \mathrm{C}$ \\
\hline-20 & $-20^{\circ} \mathrm{C}$ \\
\hline-30 & $-30^{\circ} \mathrm{C}$ \\
\hline-40 & $-40^{\circ} \mathrm{C}$ \\
\hline-50 & $-50^{\circ} \mathrm{C}$ \\
\hline-60 & $-60^{\circ} \mathrm{C}$ \\
\hline
\end{tabular}

Асортимент авіаційних пластичних мастил закордонного виробництва.

Авіаційні мастила компанії NYCO (Франція).

NYCO GREASE GN 06 - мастило на основі мінеральної оливи з кінематичною в'язкістю 5 сСт при $100{ }^{\circ} \mathrm{C}$, загущеної літієвим милом, містить графіт. Робочий діапазон температур від $-40{ }^{\circ} \mathrm{C}$ до $+121{ }^{\circ} \mathrm{C}$. Експлуатаційні характеристики: ефективні змащувальні, протизношувальні, антикорозійні та антиокислювальні властивості [19].

Використовується для стартерів двигунів внутрішнього згоряння, а також підшипників ковзання.

Специфікації мастила та допуски:

Код НАTO - NATO CODE G-355;

Франція, стандарт (F.S.) - DCSEA355/A (ex-AIR 4206);

Великобританія, стандарт (U.K.S.) - DEF STAN 91-54 Iss. 2 Amd. 1;

AIRBUS CML 03FBC1.

NYCO GREASE GN 17 - м'яке мастило на основі синтетичної діестерної оливи, загущеної літієвим милом, містить антикорозійні, антиокислювальні та протизношувальні присадки, в якості твердого наповнювача містить 5\% дисульфіду молібдену. Робочий діапазон температур від $-73{ }^{\circ} \mathrm{C}$ до $+121{ }^{\circ} \mathrm{C}$.

Мастило рекомендовано в якості багатоцільового мастила для планера (приводи, двері, закрилки, шасі,...), використовується для шпонок, пазів, антифрикційних підшипників, амортизуючих підшипників і роликів та на поверхнях ковзання [19].

Мастило відповідає класифікації NLGI: 2.

Специфікації мастила та допуски:

Код НАTO - NATO CODE G-353;

США, стандарт (U.S.S.) - MIL-G-21164 D;

F.S. - DCSEA 354/B (ex-AIR 4217, ex-DCSEA 354/A);

U.K.S. - DEF STAN 91-57 Iss. 2;

AIRBUS CML 03HEB1, ATR CML 04-002, BOEING CML D00014.

NYCO GREASE GN 10 - м'яке мастило на основі синтетичної діестерної оливи, загущеної літієвим милом, містить антикорозійні, антиокислювальні та протизношувальні присадки. Робочий діапазон температур від $-73{ }^{\circ} \mathrm{C}$ до $+121{ }^{\circ} \mathrm{C}$. 
Мастило рекомендовано в якості багатоцільового мастила для планера (приводи, двері, закрилки, рейки, шасі,...) більшості цивільних та військових літаків та вертольотів, використовується для дугоподібних, роликових і голчастих підшипників, редукторів і поверхонь тертя малопотужного обладнання [19]. Використовується мастило також в якості засобу для антикорозійного захисту.

Технічно NYCO GREASE GN 10 можна замінити на Nyco Grease GN 148.

Мастило відповідає класифікації NLGI: 2.

Специфікації мастила та допуски:

Код НАТO - NATO CODE G-354;

U.S.S. - MIL-PRF 23827 C AMDT 2 TYPE I;

F.S. - DCSEA 354/B (EX-AIR 4210);

U.K.S. - DEF STAN 91-53 Iss.3 Amd.1;

Airbus CML 03HBC1, Airbus CML 03HBD9, PWC CML PMC 79671.

NYCO GREASE GN 25013 - синтетичне мастило на основі високоякісної силіконової оливи, згущеної політетрафторетиленом, містить антикорозійні і антиокислювальні присадки. Робочий діапазон температур від $-73{ }^{\circ} \mathrm{C}$ до $+232{ }^{\circ} \mathrm{C}$. Експлуатаційні характеристики: мастило повністю сумісне з усіма типами еластомерів, крім силіконових гум [19].

Мастило рекомендовано в якості багатоцільового мастила для планера літака та вертольота (двері, закрилки, шасі,...), використовується для кулькових і роликових підшипників з особливо низьким крутним моментом при низькій температурі, для гвинтових приводів літальних апаратів. Також застосовується як в якості антизадирного мастила, при збиранні / демонтажу болтів і гайок коліс, так і в якості засобів тривалого захисту в режимах підвищених (високих) температур.

Мастило відповідає класифікації NLGI: 2.

Специфікації мастила та допуски:

Код НАTO - NATO CODE G-372;

U.S.S. - MIL-G-25013 E;

AIRBUS CML 03JDA1, ATR CML 04-010.

NYCO GREASE GN 4343 - - синтетичне мастило на основі силікону, загущеного літієвим милом. Робочий діапазон температур від $-65^{\circ} \mathrm{C}$ до $+175{ }^{\circ} \mathrm{C}$.

Мастило призначене для використання на прогумованих і металевих частинах пневматичних систем, а також гумових втулках шпангоутів [19].

Мастило відповідає класифікації NLGI: 2.

Специфікації мастила та допуски:

Код НАТO - NATO CODE G-392;

U.S.S. - SAE-AMS-G-4343;

AIRBUS CML 03JCA9, ATR CML 04-011, BOEING CML D00062

NYCO GREASE GN 22 - мастило на основі синтетичної вуглеводневої оливи 3 кінематичною в'язкістю 7 сСт при $100{ }^{\circ} \mathrm{C}$, загущене бентонітовими глинами, містить антикорозійні, антиокислювальні, протизношувальні / протизадирні присадки. Робочий діапазон температур від $-65^{\circ} \mathrm{C}$ до $+177^{\circ} \mathrm{C}$.

Мастило рекомендовано в якості багатоцільового мастила для планера (двеpi, закрилки, шасі,...) більшості цивільних та військових літаків та вертольотів, використовується для антифрикційних підшипників і підшипників ковзання, коробок передач і редукторів [19].

Мастило відповідає класифікації NLGI: 2. 
Специфікації мастила та допуски:

Код НАTO - NATO CODE G-395;

F.S. - DCSEA 395/C (ex AIR 4222);

U.S.S. - MIL-PRF-81322 G;

U.K.S. - DEF-STAN 91-52 ISS.1 AMD.2;

AIRBUS CML 03GBB1, ATR CML 04-004B, BOEING CML D00016, D00233, D00378.

NYCO GREASE GN 69 - силіконове електроізоляційне мастило на основі термостійкої силіконової оливи, загущеної гелеутворюючою речовиною, яка не плавиться [19]. Робочий діапазон температур від $-54{ }^{\circ} \mathrm{C}$ до $+204{ }^{\circ} \mathrm{C}$.

Мастило рекомендоване для електричних з'єднань високої напруги, систем запалювання та електрообладнання, різьбових і нерізьбових поверхонь (з'єднань).

Специфікації мастила:

Код НАTO - NATO CODE S-736;

U.K.S. - DEF STAN 68-69 Iss.1;

F.S. - DCSEA 636/A;

U.S.S. - AS 8660.

NYCO GREASE GN 144 - м'яке мастило, виготовлене на суміші синтетичного поліальфаолефіну та естеревої оливи, загущеної літієвим милом, містить антикорозійні, антиокислювальні та протизношувальні присадки [19]. Робочий діапазон температур від $-60^{\circ} \mathrm{C}$ до $+120^{\circ} \mathrm{C}$.

Мастило рекомендоване для механізму складання закрилків і предкрилків на повітряних судах Airbus, для приводу тримера руля висоти та привідних ланцюгів Bombardier Q400.

Мастило відповідає класифікації NLGI: 1,5.

Допуски мастила:

AIRBUS CML 03GBD1.

NYCO GREASE GN 148 -мастило, виготовлене на суміші синтетичних діефірних олив та синтетичної вуглеводневої базової основи, загущене складним літієвим милом, містить антикорозійні, антиокислювальні, протизношувальні присадки, а також спеціальну добавку для зменшення зносу деталей в умовах дії надвисокого тиску. Робочий діапазон температур від $-73{ }^{\circ} \mathrm{C}$ до $+135{ }^{\circ} \mathrm{C}$ [19]. Експлуатаційні характеристики: відмінний захист від зносу, іржі та корозії, навіть в солоній воді; висока несуча здатність при екстремальних навантаженнях; тривалий термін служби; підвищена стійкість до вимивання водою, рідинами запобігання обмерзанню і іншими рідинами; ефективне змащування підшипників в умовах вібрації.

Мастило рекомендовано в якості багатоцільового авіаційного мастила широкої сфери застосування: для змащування елементів конструкції планера (двері, закрилки, рейки, шасі, підшипники та ін.) для цивільних і військових літаків і вертольотів; для підшипників високої і надвисокої швидкості обертання; для підшипників, що працюють в режимі коливального руху; для важконавантажених систем.

Компанія NYCO врахувала властивості різних типів мастил, що використовуються в повітряних суднах, і розробила уніфіковане мастило NYCO GREASE GN 148, яке може використовуватися в максимальній кількості вузлів і агрегатів. Технічно дане мастило може замінити мастила попередніх поколінь, що відпові- 
дають вимогам MIL-PRF-23827 Тип I та II, код HATO G-382, AIMS-09-06-001, MIL-G-25537 та ін.

Мастило відповідає класифікації NLGI: 2.

Специфікації мастила та допуски:

Код НАTO- NATO CODE G-354;

U.S.S. - MIL-PRF-23827 C Amdt 2 Type I;

U.K.S. - DEF STAN 91-53, DEF STAN 91-12;

F.S. - DCSEA 354/A, DCSEA 382;

Airbus - AIMS 09-06-002;

BOEING - BMS 3-33C;

AIRBUS CML 03GBC1, 03HBC1, 03HBD9 та 03GBD1; ATR CML 04-004A та 04-024.

Авіаційні мастила транснаціональної корпорації Royal Dutch Shell, торгова марка «AeroShell» (Нідерланди -Великобританія).

Aeroshell Grease 7 - мастило на основі синтетичної базової естерної оливи, загущеної мікрогелем [20]. Робочий діапазон температур від $-73{ }^{\circ} \mathrm{C}$ до $+149{ }^{\circ} \mathrm{C}$. Експлуатаційні характеристики: висока несуча здатність в широкому діапазоні температур; ефективні антикорозійні властивості; водостійкість.

Мастило рекомендовано в якості багатоцільового мастила, відповідає практично всім вимогам, які пред'являються до мастил для повітряних суден 3 газотурбінними і поршневими двигунами, за умов, коли не виникають проблеми сумісності з ущільнювальними матеріалами. Більшість виробників пасажирських і транспортних повітряних суден схвалюють AeroShell Grease 7 як мастило загального призначення.

Мастило рекомендовано для високонавантажених зубчастих передач, приводів гвинтових механізмів та ін., а також для інструменту і авіаційних конструкцій. Оскільки мастило містить синтетичні естери, його не рекомендовано використовувати в контакті 3 деякими ущільнювальними матеріалами. Також дане мастило не рекомендовано змішувати 3 мастилами на мильній основі (за специфікацією MIL-PRF-23827C тип I), оскільки воно містить глиняну основу (відповідає специфікації MIL-PRF-23827C тип II).

Мастило відповідає класифікації NLGI: 2.

Специфікації мастила та допуски:

Код НАTO- NATO CODE G-354;

U.S.S. - MIL-PRF-23827 C Type II;

F.S. - DCSEA 354/A.

Aeroshell Grease 22 - мастило на основі синтетичної вуглеводневої базової оливи, загущеної мікрогелем; містить пакет антиокислювальних, антикорозійних, протизношувальних присадок і присадок, що підвищують несучу здатність [20]. Робочий діапазон температур від $-65^{\circ} \mathrm{C}$ до $+204{ }^{\circ} \mathrm{C}$.

Мастило рекомендовано в якості багатоцільового мастила для важких умов експлуатації.

Мастило рекомендовано для високонавантажених, високошвидкісних підшипників, що працюють в широкому інтервалі температур і потребують мастила 3 високою несучою здатністю і водостійкістю (підшипники шасі, агрегатів двигуна, систем управління, приводів, гвинтових домкратів, сервомеханізмів і електромоторів, підшипники роторів вертольотів, шарнірних болтів, інструментів, статичних з'єднань, та ін.). 
Мастило відповідає класифікації NLGI: 2.

Специфікації мастила та допуски:

Код НАTO- NATO Code G-395;

U.S.S. - MIL-PRF-81322G;

U.S.S. - DOD-G-24508A;

U.K.S. - DEF STAN 91-52;

F.S. - DCSEA 395/A;

Russian - аналог Циатим 201 та 203, ВНІІ НП 207, Ера (ВНІІ НП 286М) та HK50 [21].

AeroShell Grease 33 - мастило на основі синтетичної вуглеводневої оливи і естерів, загущене літієвім комплексом; містіть інгібітори корозії і окислення та присадки, які підвищують несучу здатність [20]. Робочий діапазон температур від $-73{ }^{\circ} \mathrm{C}$ до $+121{ }^{\circ} \mathrm{C}$. Експлуатаційні характеристики: ефективні протизношувальні та антикорозійні властивості; тривалий термін служби; підвищена стійкість до вимивання водою, рідинами запобігання обмерзанню і іншими рідинами [22].

Мастило рекомендовано в якості універсального мастила для планера, різних вузлів та агрегатів, що дозволяє скоротити експлуатантам асортимент мастил і ризик їх неправильного застосування.

AeroShell Grease 33 можна використовувати в якості багатоцільового мастила за умов, коли вказується специфікація MIL-PRF-23827C для повітряних суден, що випускаються McDonnell Douglas, Airbus, BAe Regional Aircraft, Canadair, Lockheed, Embraer, Fokker, Gulfstream i Antonov [23] (за виключенням підшипників коліс 3 температурою експлуатації вище $121^{\circ} \mathrm{C}$ та пар тертя ковзання, де необхідно застосовувати дисульфід молібдену).

Мастило відповідає класифікації NLGI: 2.

Специфікації мастила та допуски:

Код НАTO - NATO CODE G-354;

U.S.S. - MIL-PRF-23827C (Type I);

U.K.S. - DEF STAN 91-53;

F.S. - DCSEA 354/A;

Russian - аналог Ера, ОКБ-122-7;

Airbus - AIMS 09-06-002;

BOEING - BMS 3-33C.

Авіаційні мастила компанії Anderol Speciality Lubricants в структурі спеціалізованої хімічній компанії LANXESS (Німеччина), торгова марка «Rоусо» (Сполучені Штати Америки).

Royco $11 \mathrm{MS}$ - мазь сіро-чорного кольору, базова основа - мінеральна олива, загущена неорганічним гелем; містить антикорозійну та антиокислювальну присадки та добавку дисульфід молібдену [24]. Робочий діапазон температур від -40 ${ }^{\circ} \mathrm{C}$ до $+150{ }^{\circ} \mathrm{C}$. Експлуатаційні характеристики: висока несуча здатність, ефективні антикорозійні та антиокислювальні властивості, висока водостійкість, надійні характеристики при низьких температурах.

Мастило призначено для використання в парах тертя ковзання при важких умовах експлуатації (велике навантаження, висока температура, наявність агресивного середовища); рекомендовано використовувати мастило в вузлах шасі повітряних суден.

Мастило відповідає класифікації NLGI: 1 [9].

Специфікації мастила: 
Код НАTO - NATO CODE O-155;

U.S.S. - MIL - G - 7711A.

Допуск виробників Boeing, McDonnell Douglas.

ROYCO 22CF - мастило коричневого кольору на основі синтетичної оливи 3 високим індексом в'язкості (поліальфаолефіни), загущеної неорганічним гелем; містить антиокислювальні, антикорозійні, протизадирні присадки та добавки для захисту від іржі [24]. Робочий діапазон температур від $-54{ }^{\circ} \mathrm{C}$ до $+177{ }^{\circ} \mathrm{C}$. Експлуатаційні характеристики: висока несуча здатність та ефективні змащувальні властивості при високих і низьких температурах; мінімальний опір запуску при екстремально низьких температурах; високі антиокислювальні та антикорозійні властивості в жорстких умовах експлуатації за температурно-навантажувальним діапазоном; підвищена водостійкість; тривалий термін служби.

Мастило рекомендовано в якості багатоцільового мастила в багатьох галузях промисловості.

Мастило призначено для використання в підшипниках коліс повітряних суден, приладах, коробках передач, підшипниках ротора, приводах, для високошвидкісних пар тертя.

Мастило відповідає класифікації NLGI: 2 [9].

Специфікації мастила:

Код НАТO - NATO CODE G-395;

U.S.S. - MIL-PRF-81322G.

ROYCO 64 - мастило на основі термічно стійких естерів, загущених 12гідроксистеаратом літію; містить антиокислювальні, антикорозійні, AW (протизношувальні) / ЕР (протизадирні) присадки, мілкодисперсні частинки дисульфіду молібдену «Moly» [24]. Робочий діапазон температур від $-73{ }^{\circ} \mathrm{C}$ до $+135{ }^{\circ} \mathrm{C}$. Експлуатаційні характеристики: висока несуча здатність при великих навантаженнях; надійні антиокислювальні та антикорозійні властивості; ефективні протизношувальні та протизадирні властивості; стійкість до градієнту швидкості зсуву; захист контактних поверхонь в граничному та сухому режимах мащення за рахунок високої адгезії мілкодисперсних частинок дисульфіду молібдену; проникнення в поверхневі шари металевих поверхонь та формування стійкої захисної плівки.

Мастило рекомендовано використовувати для сталевих пар тертя ковзання, антифрикційних високонавантажених підшипників низької та середньої швидкості, які працюють в умовах дії екстремально низьких та високих температур.

Мастило не рекомендовано застосовувати у високошвидкісних антифрикційних підшипниках без попередньої оцінки. Стійкість дисульфіду молібдену та високі проникаючі властивості синтетичної базової основи ускладнюють видалення цього матеріалу з поверхонь. Крім того, компоненти мастила в процесі експлуатації можуть призвести до пом'якшення натурального каучуку та неопрену, а також деяких видів фарб.

Мастило відповідає класифікації NLGI: 2 [9].

Специфікації мастила та допуски:

Код НАТO - NATO CODE G-353;

U.S.S. - MIL-G-21164D;

U.K.S. - DEF STAN 91-57;

F.S. - DCSEA 353/A (ex AIR 4217/A).

Авіаційні мастила компанії WEGO (Чеська Республіка). 
Циатим-201 WEGO - мастило на основі малов'язкої мінеральної базової оливи, літієвого загусника; містить поліфункціональний пакет присадок. Робочий діапазон температур від $-60{ }^{\circ} \mathrm{C}$ до $+90{ }^{\circ} \mathrm{C}$. Експлуатаційні характеристики: ефективні антикорозійні, антифрикційні та протизношувальні властивості; відміні низькотемпературні властивості та морозостійкість; висока стійкість до вимивання водою; подовження терміну служби пар тертя [25].

Мастило призначене для вузлів тертя, які працюють 3 малим зусиллям зсуву при невисоких навантаженнях, для авіаційної техніки, радіотехнічного обладнання, електромеханічних приладів та точних механізмів. Мастило також рекомендоване для наземних механізмів, вузлів тертя автомобільного транспорту, який працює в умовах низьких температур.

Мастило відповідає класифікації DIN 51502: K1E-60, NLGI: 1; ГОСТ 23258 : Н-Либ/9-1; TU-1007 (Угорщина), NLGI 1, STAS 8961-83 (Румунія) [12, 9].

Авіаційні мастила компанії "Эксперт-Ойл" (Російська Федерація).

НК-50 (ТУ 38.1011219-95) - мазь темно-зеленого кольору, виготовляється загущенням залишкових нафтових авіаційних олив (МС-20 або МК-22) натрієвим милом стеаринової і олеїнової кислот; містить колоїдний графіт. Робочий діапазон температур від $-15^{\circ} \mathrm{C}$ до $+120{ }^{\circ} \mathrm{C}$. Експлуатаційні характеристики: незважаючи на невисоку температуру каплепадіння мастила $\left(200{ }^{\circ} \mathrm{C}\right)$, його рекомендують короткотривало використовувати до $180{ }^{\circ} \mathrm{C}$; неефективні низькотемпературні властивості; погана водостійкість (мастило при зберіганні в дерев'яній тарі здатне поглинати воду з повітря, при цьому властивості мастила в поверхневому шарі істотно змінюються (знижується температура каплепадіння, межа міцності та ін.)) [26].

Мастило призначене для підшипників, ступиць шасі повітряних суден та для шліцьових з'єднань повітряних гвинтів.

Мастило відповідає класифікації DIN 51502: KF4K-15; ГОСТ 23258-78: УНа 2/15-Г4 [12].

Мастило СЕДА (ТУ 38.1011242-89 змін. 1-4) - композиція складних ефірів (естерів), загущена комплексним милом стеарату та ацетату кальцію; містить протизношувальні і антиокислювальні присадки [27]. Робочий діапазон температур від $-60{ }^{\circ} \mathrm{C}$ до $+120{ }^{\circ} \mathrm{C}$. Експлуатаційні характеристики: ефективні змащувальні і низькотемпературні властивості; низька випаровуваність; задовільна водостійкість; обумовлює набухання гуми на основі нітрильних і силоксанових каучуків.

Мастило призначене для змащення слабонавантажених швидкісних підшипників кочення електричних машин (електрогенераторів, стартер-генераторів) повітряних суден.

Мастило ВНІІ НП-261 Сапфір (ТУ 38.1011051-87) - мастило на основі термостійких олив та загусників [28]. Робочий діапазон температур від $-40{ }^{\circ} \mathrm{C}$ до $+150{ }^{\circ} \mathrm{C}$, короткочасно до $+200{ }^{\circ} \mathrm{C}$. Експлуатаційні характеристики: високі термостійкість, механічна і антиокислювальна стабільності.

Мастило призначене для конічних роликових підшипників ступиць коліс шасі, які тривалий час працюють в широкому температурному діапазоні в умовах різкозмінних навантажень і частот обертання. Мастило застосовується в шліцьових з'єднаннях повітряних гвинтів літаків і вертольотів, в різьбових з'єднаннях.

Мастило відповідає класифікації DIN 51502: K3N-55 [12]. 
Мастило Ера (ВНІІНП-286М) (ТУ 38.101950-83) - суміш олив гідрокрекінгу і гідроізомеризації, загущена кислотами гідрованої касторової олії і літієвим милом стеаринової кислоти; містить протизадирну і антиокислювальну присадки [29]. Робочий діапазон температур від $-60{ }^{\circ} \mathrm{C}$ до $+120{ }^{\circ} \mathrm{C}$. Експлуатаційні характеристики: високі антиокислювальні та антикорозійні властивості; висока механічна стабільність; ефективні протизадирні і протизношувальні характеристики; інертність при контакті з гумою; водостійкість; висока морозостійкість; низька колоїдна стабільність.

Мастило застосовується в зубчастих передачах, підшипниках ковзання і кочення різних систем управління повітряних суден; застосовується в підшипниках ротора гіроскопа.

Мастило відповідає класифікації DIN 51502: КР2-3К-60 [12].

\section{Висновки.}

Виготовлення високотехнологічних та високоефективних авіаційних, промислових та автомобільних мастильних матеріалів з заданими характеристиками $\epsilon$ однією з першочергових задач для підвищення надійності пар тертя. Вибір мастила за певною системою класифікації відповідно до фізико-хімічних, механічних та експлуатаційних властивостей дозволяє більш ефективно використовувати його в вузлах тертя певного призначення.

Проаналізовані в роботі системи класифікації мастил у відповідності до міжнародних стандартів NLGI та DIN, які встановлюють систему позначення, ідентифікації і вимоги щодо фізико-механічних властивостей мастильних матеріалів для конкретних умов використання відповідного механізму.

Наведений асортимент авіаційних пластичних мастил провідних закордонних виробників. Зазначено тип основи, загущувача, наявність наповнювачів в мастилі, його експлуатаційні характеристики та рекомендації виробників щодо цільового застосування мастила в конкретних вузлах тертя. Для розглянутих авіаційних мастил зазначені специфікації та допуски, встановлені провідними виробниками авіаційної техніки, зокрема Airbus, Boeing, McDonnell Douglas, Embraer.

\section{Список літератури}

1. Дмитриченко М. Ф. Триботехніка та основи надійності машин: Навчальний посібник / М. Ф. Дмитриченко, Р. Г. Мнацаканов, О. О. Мікосянчик. - Київ: Інформавтодор, 2006. - $216 \mathrm{c}$.

2. Закалов, О.В. Основи тертя і зношування в машинах: Навчальний посібник / О.В. Закалов, І.О. Закалов. - Тернопіль: Видавництво ТНТУ ім. І.Пулюя, 2011. - 322 с.

3. Chapter One The Definition and Classification of Lubricants [Електронний ресурс] // Tribology Series. - 2008. - Режим доступу до pecypcy: https://doi.org/10.1016/S01678922(08)70348-1.

4. Lubricants : Classification and properties [Електронний ресурс]. - 2014. - Режим доступу до ресурсу: http://ecoursesonline.iasri.res.in/mod/page/view.php?id=993.

5. Kunselman M. NLGI New Grease Specification Update [Електронний ресурс] / M. Kunselman, Y. Starks // NLGI. - 2019. - Режим доступу до ресурсу: https://www.nlgi.org/wp-content/uploads/2020/01/Press-Release-October-2019.pdf.

6. Классификация пластичных смазок NLGI [Електронний ресурс] / jjjj // УКРАВТОЗАПЧАСТЬ. - 2012. - Режим доступу до ресурсу: http://uazupi.com/ru/node/7009/klassifikatsiya-plastichnykh-smazok-nlgi.

7. ASTM D4950 - 19 Standard Classification and Specification for Automotive Service Greases. 
8. DIN 51818 Lubricants; consistency classification of lubricating greases; NLGI grades.

9. NLGI GREASE Service Classification [Електронний ресурс] // CHS Inc. - 2020. Режим доступу до ресурсу: https://www.chsinc.com/farmoyl/resources/nlgi-grease-serviceclassification.

10. Greases [Електронний ресурс] - Режим доступу до ресурсу: https://www.boucherandjones.com/grease.htm.

11. Deutsches Institut für Normung e. V., https://www.din.de/en/about-standards/a-briefintroduction-to-standards.

12. DIN 51502: 1990. Lubricants and related materials; designation of lubricants and marking the containers for lubricants, lubrication equipment and lubrication points.

13. DIN 51825 : 2004-06. Lubricants - lubricating greases $\mathrm{k}$ - classification and requirements.

14. DIN 51826-2015 Lubricants - Lubricating greases G - Classification and requirements.

15. ISO 19378:2003 Lubricants, industrial oils and related products (class L) - Machinetool lubricants - Categories and specifications.

16. DIN 51807-1. Testing of lubricants - Test of the behaviour of lubricating greases in the presence of water - Part 1: Static test.

17. DIN 51819-2 : 2016. Testing of lubricants - mechanical-dynamic testing in the roller bearing test apparatus FE8 - Part 2: test method for lubricating greases - applied test bearing: oblique ball bearing or tapered roller bearing.

18. DIN 51821-2. Testing of lubricants - Test using the FAG roller bearing grease testing apparatus FE9 - Part 2: Test method.

19. NYCO Grease. Technical Data Sheet. https://www.nyco-group.com/fr/produits/nycogrease/.

20. The AeroShell Book. - 2012. - Режим доступу до ресурсу: https://www.shell.com/business-customers/aviation/aeroshell/knowledge-centre/the-aeroshellbook/_jcr_content/par/textimage_1433441235.stream/1519764636322/2450d6be71ecb544ed6 6e557f856b8e59a15ae28/aeroshell-book-5greases.pdf.

21. Вітчизняні пластичні мастила і їх зарубіжні аналоги / [К. Баранський, Н. Курилюк, О. Ніколайчук та ін.]. - Київ, 2009. - 34 с. - (Методичні рекомендації по хіммотології № 58).

22. Протизадирні властивості мастила Aero Shell Grease 33 при використанні конструкційних сталей 9ХС і 30ХГСА / [О. С. Якобчук, Р. Г. Мнацаканов, О. О. Мікосянчик та ін.]. // Проблеми тертя та зношування. - 2018. - №1. - С. 27-36.

23. Якобчук О. С. Анализ можливості заміни мастила ВНІІНП - 286М Ha Aero Shell Grease 33 у вузлах механізації крила у літаках сімейства АН / О. Є. Якобчук. // Проблеми тертя та зношування. - 2019. - №2. - С. 29-36.

24. Anderol Product Data Sheets / - Merry Lane East Hanover, New Jersey USA: ANDEROL. - (ANDEROL Specialty Lubricants). 2002.

25. WEGO ЦИАТИМ-201. // Технический паспорт / - Москва: ЗАТ "Вего Рус", 2015.

26. Смазка НК-50. ТУ 38.1011219-95. [Електронний ресурс] // Режим доступу до реcypcy: $\quad \underline{\text { http://zao-zish.ru/produktsiya/plastichnyie/antifriktsionnyie/spets/dlya-avia-morsk- }}$ nazem-teh/smazka-nk-50/.

27. Смазка СЭДА. ТУ 38.1011242-89 [Електронний ресурс] // Смазочная компания. - 2020. - Режим доступу до ресурсу: http://smazka.perm.ru/index/seda/0-57.

28. Aquiline International Corporation LTD. - 2020. - Режим доступу до ресурсу: http://trast-aero.com/ru/catalog/Masla-i-smazki/VNII-NP-261-Saphire.html.

29. ТУ 38.101950-00 Смазка Эра (ВНІІНП-286М). Технические условия. 
Мнацаканов Рудольф Георгійович - д. техн. наук, професор, професор кафедри підтримання льотної придатності повітряних суден, Національний авіаційний університет, пр. Любомира Гузара, 1, м. Київ, Україна, 03058, тел.: +38 04440678 56, E-mail: mnatsakanov@ukr.net.

Мікосянчик Оксана Олександрівна - д. техн. наук, професор, професор кафедри механіки, Національний авіаційний університет, пр. Любомира Гузара, 1, м. Київ, Україна, 03058, тел.: +38 04440678 91, E-mail: oksana.mikos@ ukr.net.

Якобчук Олександр Євгенійович - старший викладач кафедри підтримання льотної придатності повітряних суден, Національний авіаційний університет, пр. Любомира Гузара, 1, м. Київ, Україна, 03058, тел.: +38 044406 72 58, E-mail: a-yak@ukr.net

Хімко Андрій Миколайович - канд. техн. наук, доцент, доцент кафедри підтримання льотної придатності повітряних суден, Національний авіаційний університет, пр. Любомира Гузара, 1, м. Київ, Україна, 03058, тел.: +38044 40672 58, E-mail: andreykhimko@ukr.net

Харченко Олена Василівна - канд. техн. наук, доцент кафедри Технологій аеропортів, Аерокосмічного факультету, Національного авіаційного університету, пр. Любомира Гузара 1, м.Київ, 03058, тел.: +380444067326, E-mail: olena80@ukr.net

Стаття надійшла до редакції 24.09.2020. 
R. G. MNATSAKANOV, O. O. MIKOSIANCHYK, O. YE. YAKOBCHUK,

A. M. KHIMKO, O. V. KHARCHENKO

\section{REVIEW OF OILS CLASSIFICATIONS OF FOREIGN PRODUCTION BY PHYSICAL-MECHANICAL AND OPERATIONAL PROPERTIES}

The article presents an overview of physical, mechanical and operational characteristics of foreign lubricants. In the article presented NLGI and DIN system classifications. The classification of oils and lubricants discussed by the difference between these systems and the peculiarities. Requirements for the quality of lubricants and oils presented according to the NLGI classification. The National Lubricating Grease Institute developed the NLGI classification of lubricants. NLGI developed the automotive oil quality category defined in ASTM D4950 "Standard Classification and Specification for Automotive Service Oils" in collaboration with ASTM International and SAE International. NLGI classification includes the distribution of lubricants by consistency (viscosity or density) and quality categories. The operating temperature requirements and the field of application recommended for lubricants with different degrees of viscosity.

The article presents considerable attention to DIN classification systems. The German standard DIN 51502-1990 established a single system for marking and identification of lubricants. The unified classification of lubricants by type, application, consistency, water resistance, maximum and minimum operating temperature, and type of additives included in the grease, allows you quickly and easily to select the lubricant for specific conditions of application, of the mechanism, identify all characteristics by labelling. The standard establishes the classification of lubricants depending on the areas of application, type of dispersion medium, the presence of anti-wear and antifriction additives, fillers, and takes into account their water resistance and temperature range of application.

The range of aviation greases of foreign production quite fully are discussed in this paper. The analysis of lubricants of NYCO (France), AeroShell (Netherlands - Great Britain), Royco (United States of America), WEGO (Czech Republic), Expert Oil (Russian Federation) different companies and trademarks presented in this article.

The most common and widespread aviation lubricants and their characteristics, operating parameters and endurance limits analyzed and presented in this paper.

Keywords: classification of oils, greases, workability, aviation lubricants, automotive lubricants, wear, penetration, consistency, reliability, friction.

\section{Referenses}

1. Dmitrichenko M. F. Tribotehnika ta osnovi nadijnosti mashin: Navchal'nij posibnik / M. F. Dmitrichenko, R. G. Mnacakanov, O. O. Mikosjanchik. - Kiïv: Informavtodor, 2006. $216 \mathrm{~s}$.

2. Zakalov, O.V. Osnovi tertja i znoshuvannja v mashinah: Navchal'nij posibnik / O.V. Zakalov, I.O. Zakalov. - Ternopil': Vidavnictvo TNTU im. I.Puljuja, 2011. - 322 s.

3. Chapter One The Definition and Classification of Lubricants [Electronic resource] // Tribology Series. - 2008. - Access to resources: https://doi.org/10.1016/S01678922(08)70348-1.

4. Lubricants : Classification and properties [Electronic resource]. - 2014. - Access to resources: http://ecoursesonline.iasri.res.in/mod/page/view.php?id=993.

5. Kunselman M. NLGI New Grease Specification Update [Electronic resource] / M. Kunselman, Y. Starks // NLGI. - 2019. - Access to resources: https://www.nlgi.org/wpcontent/uploads/2020/01/Press-Release-October-2019.pdf.

6. Classification of greases NLGI [Electronic resource] // UKRAVTOZAPCHAST. 2012. - Access to resources: http://uaz-upi.com/ru/node/7009/klassifikatsiya-plastichnykhsmazok-nlgi. 
7. ASTM D4950 - 19 Standard Classification and Specification for Automotive Service Greases.

8. DIN 51818 Lubricants; consistency classification of lubricating greases; NLGI grades.

9. NLGI GREASE Service Classification [Electronic resource] // CHS Inc. - 2020. Access to resources: https://www.chsinc.com/farmoyl/resources/nlgi-grease-serviceclassification.

10. Greases [Electronic resource] - Access to resources: https://www.boucherandjones.com/grease.htm.

11. Deutsches Institut für Normung e. V., https://www.din.de/en/about-standards/a-briefintroduction-to-standards.

12. DIN 51502:1990. Lubricants and related materials; designation of lubricants and marking the containers for lubricants, lubrication equipment and lubrication points.

13. DIN 51825:2004-06. Lubricants - lubricating greases $\mathrm{k}$ - classification and requirements.

14. DIN 51826-2015 Lubricants - Lubricating greases G - Classification and requirements.

15. ISO 19378:2003 Lubricants, industrial oils and related products (class L) - Machinetool lubricants - Categories and specifications.

16. DIN 51807-1. Testing of lubricants - Test of the behaviour of lubricating greases in the presence of water - Part 1: Static test.

17. DIN 51819-2 : 2016. Testing of lubricants - mechanical-dynamic testing in the roller bearing test apparatus FE8 - Part 2: test method for lubricating greases - applied test bearing: oblique ball bearing or tapered roller bearing.

18. DIN 51821-2. Testing of lubricants - Test using the FAG roller bearing grease testing apparatus FE9 - Part 2: Test method.

19. NYCO Grease. Technical Data Sheet. https://www.nyco-group.com/fr/produits/nycogrease/.

20. The AeroShell Book. - 2012. - Access to resources: https://www.shell.com/businesscustomers/aviation/aeroshell/knowledge-centre/the-aeroshellbook/_jcr_content/par/textimage_1433441235.stream/1519764636322/ 2450d6be71ecb544ed66e557f856b8e59a15ae28/aeroshell-book-5greases.pdf.

21. Vitchiznjani plastichni mastila i ïh zarubizhni analogi / [K. Barans'kij, N. Kuriljuk, O. Nikolajchuk ta in.]. - Kiïv, 2009. - 34 s. - (Metodichni rekomendaciï po himmotologiï № 58).

22. Anti-slip properties of Aero Shell Grease 33 lubricant at using of structural steels 9XC and 30ХГСА / [O. Ye Yakobchuk, R. G. Mnatsakanov, O. O. Mikosianchyk, A. N. Khimko, V. V. Tokaruk]. // Problems of friction and wear. - 2018. - №1. - pp. 27-36.

23. Yakobchuk O. Ye. Analysis of the possibility of replacing the VNIINP -286M lubricant on the Aero Shell Grease 33 in the high lift devices of the wing of the AN-family aircraft / O. Ye Yakobchuk. // Problems of friction and wear. - 2019. - №2. - pp. 29-36.

24. Anderol Product Data Sheets / - Merry Lane East Hanover, New Jersey USA: ANDEROL. - (ANDEROL Specialty Lubricants). 2002.

25. WEGO CIATIM-201. // Technical passport / - Moscow: ZAT "Wego Rus", 2015.

26. NK-50 Smazka. TU 38.1011219-95. [Electronic resource] // Access to resources: http://zao-zish.ru/produktsiya/plastichnyie/antifriktsionnyie/spets/dlya-avia-morsk-nazemteh/smazka-nk-50/.

27. Cmazka SJeDA. TU 38.1011242-89 [Electronic resource] // Smazochnaja kompanija. - 2020. - Access to resources: http://smazka.perm.ru/index/seda/0-57.

28. Aquiline International Corporation LTD. - 2020. - Access to resources: http://trastaero.com/ru/catalog/Masla-i-smazki/VNII-NP-261-Saphire.html.

29. TU 38.101950-00 Smazka Эra (VNIINP-286M). Tehnycheskye uslovyja. 